Illinois State University

ISU ReD: Research and eData

Theses and Dissertations

3-26-2017

\title{
Open mic: a documentary film exploring humorous narratives
}

Ryan T. Cashman

Illinois State University, rtcashm@ilstu.edu

Follow this and additional works at: https://ir.library.illinoisstate.edu/etd

Part of the Communication Commons

\section{Recommended Citation}

Cashman, Ryan T., "Open mic: a documentary film exploring humorous narratives" (2017). Theses and Dissertations. 720.

https://ir.library.illinoisstate.edu/etd/720

This Thesis is brought to you for free and open access by ISU ReD: Research and eData. It has been accepted for inclusion in Theses and Dissertations by an authorized administrator of ISU ReD: Research and eData. For more information, please contact ISUReD@ilstu.edu. 


\title{
OPEN MIC: A DOCUMENTARY FILM EXPLORING HUMOROUS NARRATIVES
}

\author{
Ryan T. Cashman
}

\section{Pages}

This documentary investigates hardship and identity through humor. The film shadows the lives of three individuals who are all going through a watershed experience with their identities ranging from changes in their family dynamics, gender, or environment. Participants will be writing and performing a stand-up routine in front of a live audience that focuses on a story about their identity. The film underscores how, or if, the sender's use of humor helps them cope or achieve closure. The film does not explore the audience's reaction to humor. Using indepth interviews with each comic, the film centers around the sender, highlighting the intrapersonal impact communicating through humor has on them. The scope of topics within the interviews include recounting their adversity, understanding their coping methods, discovering their humor style, and reflecting on their comedy performance in the context of their hardship.

KEYWORDS: humor; hardship; narrative; identity; sensemaking; coping 
OPEN MIC: A DOCUMENTARY FILM EXPLORING HUMOROUS NARRATIVES

RYAN T. CASHMAN

A Thesis Submitted in Partial Fulfillment of the Requirements for the Degree of MASTER OF SCIENCE

School of Communication

ILLINOIS STATE UNIVERSITY 
(C) 2017 Ryan T. Cashman 
OPEN MIC: A DOCUMENTARY FILM EXPLORING HUMOROUS NARRATIVES

RYAN T. CASHMAN

COMMITTEE MEMBERS:

Brent K. Simonds, Co-Chair

Maria A. Moore, Co-Chair

Lance Lippert 


\section{ACKNOWLEDGMENTS}

I would first like to thank my committee co-chair, Dr. Maria Moore and Dr. Brent Simonds for being the nervous system for this project and not allowing me to take my foot off the acceleration. First, Dr. Moore, thank you for your much needed tough love and organization. As someone who understands my temperament, thank you for adapting and finding solutions that allowed me to stay on track throughout the entire process. Also thank you for all that you personally invested to make this project work.

Additionally, Dr. Simonds, thank you for your expertise in documentary making and in helping me craft a road map to make my vision come alive on screen. You truly showed me how blessed unrest can be an extremely fulfilling head space. Moreover, I would like to thank Dr. Lance Lippert. You played a crucial role in giving a creative perspective and you were there for me during my injury and helping to organize my thoughts when I was developing this project. Also your levity during this project was much appreciated!

I would like to also thank my performers throughout the process. Thank you to my wounded storytellers: Becca, Seth, Damon, Nolan, and Eli. Thank you for sharing your stories and being vulnerable. This project in any capacity is a tough task to undergo. All of you showed true tenacity and an emotional intellect to not both understand yourselves in a new way, but also teach others who are searching for closure and sensemaking.

Finally, I would like to thank Katie Cutler, Mike Schiff, Adam Mason, Jess Gabl, Jillian Joyce, my sister, my Mom, and my Dad. My family was vital in completing this project, and I could not have done this without them. The people I named above were the reason this project was able to be completed.

R. T. C. 


\section{CONTENTS}

Page

ACKNOWLEDGMENTS

CONTENTS

CHAPTER I: SUMMARY

CHAPTER II: TREATMENT 4

Introduction of main characters $\quad 5$

Setup: Pinpointing the hardship $\quad 5$

$\begin{array}{ll}\text { Punchline: Confronting the adversity } & 6\end{array}$

Applause: Reflection on the experience $\quad 7$

CHAPTER III: FUNDING $\quad 8$

CHAPTER IV: REVIEW OF LITERATURE 9

Communicating through humor and laughter 9

The Satellites of humor and laughter 11

Comic's identity: A vulnerable expression 16

Coping with hardships via humor: Resilience and therapy 20

$\begin{array}{ll}\text { Conceptual Shows } & 23\end{array}$

Sensemaking: Uncovering an authentic identity 25

Reifying the literature: Documentary proposal 28

REFERENCES 29 


\section{CHAPTER I: SUMMARY}

Everyone experiences hardship. Some of these negative experiences may feel trivial such as not making a sports team or receiving a failing grade. Other circumstances may be more dramatic such as losing a loved one or a going through a divorce. Hardship can even be lifealtering such as coming to terms with sexuality, surviving cancer, or feeling safe in one's own skin. Whatever the adversity, inconsequential or tumultuous, the events one endures in their past is foundational to who they are today.

Undergoing hardship is common, however how one rises above their experience is idiosyncratic for each person. There are many different ways people try to cope with tragic events and some never find closure leading to frustration, anger, and depression. Some people may turn to social workers, who are available to listen and potentially help reframe one's troubles. Others may find support groups, either face-to-face or on social media, which help people persevere through a tough time. Even friends and family can act as a source for comfort. Regardless of how people receive help the process of moving past one's hardship is journey that is unique to them.

One particular way people can reframe their hardship is through humor. Humor can be an extremely conducive way to reframe hardship due to its way of heightening an issue to ridiculousness and hilarity (Panchelli, 2013). Going out to see comedy has historically been a means for people to escape their tribulations and frustrations in life. Additionally, it may give a new perspective on problems the audience may be feeling at the time. For example, when Rodney Dangerfield tells a joke about how his family was so poor that for his birthday his father gave him a picture of a cake, the audience may laugh in solidarity about their own financial troubles and think maybe their economic woes are not so bad. Even when topics about 
unconventional issues come up, such as Mike Birbiglia's solo show "My Girlfriend's Boyfriend" (Birbiglia, Birbiglia, \& Barrish, 2013), which is a humorous show about how he was the boyfriend of a girl... who had a boyfriend at the time. This shows how people can laugh at other people's uncomfortable situations, and ultimately allow them to realign their own problems in a healthier way. Think of it as humor allows the audience to view the bright (or funny) side of life's worries.

However, rarely is there a conversation about how comedy affects the comic themselves. When Louis C.K. or Sarah Silverman perform in front of their audiences, they want their audience to laugh, but also they are expressing a frustration themselves. I argue that it is in this space, when viewing humor through the lens of the sender, that the true value and functionality of humor is uncovered.

In all humor they perform, comics expose truths about who they are as people. It is in this moment that humor transcends audience laughter and critique and enables the comic to achieve feelings of catharsis, closure, and resilience.

In stand up, a successful routine has a combination of both content and genuineness. It simply would not be as funny if Louis C.K. did a joke that was Sarah Silverman's because he does not carry the same context that she does. No matter the amount of experience a comic has, when they perform, they are purposefully putting themselves in a vulnerable place. In other words, the humor comes from not only what makes an audience laugh but the authenticity of the person performing the joke.

In this documentary, I explore the lives of six individuals who are all going through a troubling time in their lives. I should note that none of them are professional comics. I ask them all to write down their hardship as a stand up set and then perform their stand up in front of a live 
audience, much like a professional comic would. Through out the film, I will follow their everyday lives as they interact with their friends and family, their work, and their time writing their stand up performance alone. I will also use in-depth interviews to hear their story in the context of both a humorous and a serious narrative. The actual comedy performances will be recorded and incorporated into the film. The film aims to answer the question: what is the threshold when the audience no longer matters and the humor is specifically there to serve the performer? Additionally, the film attempts to discover how the comic sees themselves before, during, and after the performance, and the implications their performance has on their identity. 


\section{CHAPTER II: TREATMENT}

In an underground theater in Chicago, patrons find their seats as they prepare to watch a free stand up show. Some are friends of tonight's comics. Others are complete strangers. All are ready to laugh. The comics, mostly from Chicago, are back stage, or riding the city transit to the open mic location, reviewing their material and shaking off any residual nerves they may have before they go onstage. None have ever done what they are about to do. The performers are tasked with confronting an adversity in their life by retelling it as a stand up comedy set in front of a live audience.

Enter the lives of three individuals who have experienced some sort of destitution. Their stories open up a vulnerable approach on hardship, showing a perspective about humor that has historically been ignored in past literature. That perspective is the value humor has on the sender not just the audience. The film will use establishing shots of each person's environment and their stand up performances as a subtle way to divide each story into "chapters." Through these chapters, the film aims to establish each individual performer's experience, as well as interweave between performers lives and stories. The approach to the film highlights the overarching narrative about people dealing with hardship through humor, each section juxtaposing a person's style of humor with their true crisis. I will follow these performers throughout the semester, highlighting their family dynamics and their process in writing their stand up. All the performers share the commonality of hardship and identity. These factors will be explored throughout the documentary. 


\section{Introduction of main characters}

Each individual is going through a transition with their identity, some more blatant than others. The six individuals do not know each other on a personal level, however some may know of one another. Seth is a seasonal kayak tour guide, improviser, and clown in Chicago. In high school he found out that his Mom identified as a lesbian and has since chose her partner. As he retells his story about his acceptance for his mother's sexual orientation, he starts to figure out who he is too.

Becca is 24, and a former child star from the Jack Black blockbuster film School of Rock. Becca tells us her journey of trying to find her voice and about how the decisions she has made as a woman, a former child celebrity, and as a person of color have given her great happiness and great sorrow. She also delves into the hardships of dating and relationships of being with people that would rather access her status than see her for who she is.

Damon is a 27-year-old writer and improviser. Damon struggles to understand the dating world as a gay man of color. In his story, Damon tries to discern what he wants in a relationship versus what he needs, all while trying to keep it a secret from his separated parents. His story is about his journey to redefine love for himself.

\section{Set up: Pinpointing the hardship}

The film uses parts of the performers stand up to transition between their stories. During this segment, I will use in-depth interviews and vérité style shooting to give an authentic view of the participant's life and identity. This would include introducing who the performers are, their style of comedy, and how they view themselves currently. In this section, I will also introduce other characters that are important to the performer's stand up and to their lives. I will also use archival video, such as home movies, to give more context of how the people in their lives have 
made them who they are today. Some of the interviews will be used to show the point when their lives became disrupted. This section mostly will set up the exposition of each person, as well as the inciting incident to each of their stories. I will ask questions such as: Was there a funny time trying to communicate with your father? What style of comedy do you perform? Why did you decide to make a career in Chicago? What was your relationship with your mom when she was married to your dad? The mood is a bit lighter and exploratory, as it introduces the "characters" in each story. The audience will also get a sense of each performer's stand up as it transitions between each participant. It begins to contrast how the person frames their story in an interview form, from how they frame that same story in their stand up set. Much like a joke, the set up will be extremely important to the foundation of each person's narrative. Unlike what I describe in the following section, the plot lines are separated so the audience can understand each person's account on its own.

\section{Punchline: Confronting the adversity}

After establishing each participant's experience, the film begins to meld each person's story into that overarching narrative mentioned earlier. The stories will begin to intertwine even more, highlighting certain emotional themes. Emotions of confusion, rage, loneliness, and desperation will be highlighted here. The stand up footage and audience laughter may feel eerier, overlapping with more emotionally charged interviews, real life experiences, and archival home videos. The performer's daily routines will also be examined, but more time will be spent with them writing their stand up set or getting to the climax of their performances. I will ask questions that will lead toward an understanding their struggles with their own identities. Specifically, I will ask questions like when did lying about your sexual orientation to your family get to be too much? Do you sometimes wish you had not transitioned? Was there a time specifically when you 
were embarrassed by your mother? This section will be more reflective as to why they feel a certain way to themselves or their relationships. Additionally, the stand up material will become more apparent, since earlier it was used more as a transitionary device. At this point the audience may begin to see the climax of some performances, while others will be close to the big reveal to their story. Choosing when to highlight those climaxes will be contingent on the performer's interviews and editing decisions.

\section{Applause: Reflection on the experience}

The comics in this section will resolve their stand up in this part. I should note that resolution does not always result in a happy ending. Some sets will still end in confusion. Others may reveal something uncomfortable about themselves. In comedy, specifically stand up, it is not uncommon for the end of the routine to unearth a whole new problem. Before each performer's stand up routine, I will ask them how they are feeling before going onstage. Some might feel nervous; others may not feel anything. After their stand up routine, I will again ask them to reflect on how they feel in that moment, and if they gleaned anything from this experience. Again, some may feel closure from telling their story, while some may become frustrated for opening up old wounds from their past. Regardless of how it makes the comic's feel, this documentary will lend itself to implications regrading humor and performance, and the importance those variables have on the sender. 


\section{CHAPTER III: FUNDING}

Most of my expenses will go to travel. In terms of equipment, I am able to participate in Student Television Workshop (STW), which is an extra-curricular group through the School of Communication. Through participating within this group, and $\$ 20$ admission fee, I will be able to utilize all of their equipment, including, but not limited to: A Canon C 100 camera, tripods, camera slider, lavalier mics, light kits and SD cards. I will also be using my iPhone 6 to film in HD. In fact, STW just received a component made for the iPhone 6 , in conjunction with a free app DJI GO, to transform my iPhone 6 into a steady cam. In terms of editing, I have 42 computers available to you in Fell 102 and 052 utilizing either Adobe Premiere Pro editing software. Additionally, I have licensed Adobe Premiere Pro for two months so I can continue editing off campus.

I plan to film in Chicago mostly, but since one of the participants is from Nebraska, I will have to work out a time with her to meet, either the next time she is in Chicago or I will have to make a trip out there. In Chicago I will use my current lodging arrangements since I have both fiends and family that will allow me to stay with them for free. Travel will be most weekends throughout the year. However, I will only fund travel expenses that is particularly for filming the documentary. I project that my travel expenses for the documentary will total about $\$ 300$ dollars for all the Chicago trips.

All of the participants who appear in the documentary will be unpaid volunteers. Archival footage will be used in the documentary and I plan to obtain that material from the participants, with their permission. The venue will be at an undisclosed comedy theater in Chicago. The venue will be $\$ 100$ to occupy and film. All music in the documentary will be created through the comedian's performance. 


\section{CHAPTER IV: REVIEW OF LITERATURE}

\section{Communicating through humor and laughter}

Humor has taken on an elusive form in society's history. In ancient times, humor was described as “...moisture or vapor. In old physiology, humor was a fluid or juice that circulated within the body, influencing one's disposition, mood, or state of mind" (Hoyt, 2009, p. 287). From mystical to practical, humor has transcended more than silliness today, although that is certainly still part of the concept. There is also a sense of tendentiousness or polemic to the craft (Krefting, 2014; Freud, 1976/1905). Humor's framework has become an even more ubiquitous and permeable idea since it has latched itself to a horde of different contexts. From a social perspective, Nabi, Moyer-Guse, and Byrne (2007) compared humor used between Bill Maher and Chris Rock finding that more controversial messages, when attached to humor, make some messages more memorable and potentially more persuasive than others. In a rhetorical analysis of The Daily Show, Self (2011) discovered that when people watch political, satirical shows like the The Daily Show they are not just laughing, but "also exposing themselves to argument" (p. 69). Within a political context, Becker and Haller (2014) supported Self's (2011) findings in their qualitative analysis of Saturday Night Live's parody of New York Governor David Patterson that certain types of comedy can blur the line between political and personal opinions of public figures. When comparing the success of humor in Italian literature, Pirandello (1974) believed "humor is a particular kind of artistic expression whose existence cannot be denied merely because all expression is art and therefore not distinguishable" (p. 33). As humor evolved it continued to be a mainstay within society and a deeply entrenched value in our lives.

Employed humor is, in part, to display an extension of oneself as well. From a psychoanalysis approach to humor, Freud (1976/1905) believed humor stems from an amoral 
part of our psyche. The purpose of humor to Freud was to make light of otherwise serious and sexually unprincipled ideas. Humor allowed these taboo issues that otherwise are not appropriate to discuss and for our consciousness to undergo a catharsis and release the tension attached to unsuitable thoughts. While his theory oversimplified humor's massive impact on individuals, it gave a glimpse into how humor and our consciousness connect to each other. Freud continued his edification of humor by relating it to that of dreams. He wrote "nonsense in jokes is made to serve the same aims as representation" (p. 234). This nonsense could represent an indication of our own authentic identity.

The complement to humor - laughter - is easily identified but just as nebulous to define. Bakhtin (1984) highlighted laughter during the Renaissance as a product of uncivilized taste, writing that "laughter is light amusement of a form of salutary social punishment of corrupt and low persons" (p. 67). Among the ranks of jesters, laughter was the product of "literary creation and appreciation" (Bakhtin, 1984, p. 67). The benefits of laughter, when successful, can act as a "conversation starter, tension-breaker or therapeutic intervention, laughter is a highly effective way to stimulate communication" (Lovorn, 2008, p. 2). From an anthropological perspective, Bateson (1953) commented on our - at times uncontrollable - ability to laugh, stating, "one tends to think of these phenomena as lower functions, animalish functions" (p. 2). However as evidenced by our dynamic and complex relationships, laughing may not be a simple reaction to the whimsical parts of life, but rather something that makes us "ccharacteristically human"” (p. 2). The importance of understanding the multiple satellites that invoke humor is that it helps us understand not only when we laugh, but also why we laugh. Before this, Freud (1976/1905) saw laughter as a potential symptom of humor. People have laughed for a multitude of reasons. 
However, laughter is a hard-wired reaction in our systems. That is, laughter is not something taught, but rather it is through our own biological makeup that humans have the ability to laugh. The satellites of humor and laughter

Humor and laughter are amorphous concepts, making them hard terms to define (Freud, 1976/1905; Berger, 1993; Meyer, 2000; DiCioccio, 2015). Lewis (1989) highlighted the difficulty in reifying humor due to society feeling they inherently know what humor is. Weems (2014) added to this argument, saying a huge obstacle with humor is how one measures it. Chapman and Foot (1976) argued the issue of researching and/or measuring humor is the implicit nature of humor. While this might allow researchers to identify when humor may occur it gives an extremely limited view of understanding all the idiosyncrasies of how humor affects us. After Freud's dream-like approach to humor, researchers have promoted three theoretical ideas: arousal/relief, superiority, and incongruity. These ideas have highlighted the ways humor affects interpersonal relationships (Freud, 1976/1905; LaFave et. al, 1976; Zillman \& Cantor, 1972; Meyer, 2000). These humor styles are all used to critique institutions, establish power, introduce perspective, and manipulate emotions - all with the goal to elicit laughter from an audience.

The humor theory of arousal/relief/release is the physical and psychological release of energy due to humorous messages (Graham, Papa, \& Brooks 1992; Berlyne, 1969; Martin 2007). The relief experienced by someone may be in the form of cognitive release that reduces anxiety or a physical release that reduces tension. In a study about catharsis, Leak (1974) concluded that certain jokes mitigated hostile behaviors and tension. Nueve (1988) aligned with this study arguing that humor can help relieve any covert aggression pent up in our bodies. Fry (1963) argued that laughter has a physiological impact on the body, explaining that emotional tension 
which contributes to stress is lowered through the cathartic effects of humor. Through these examples, laughter could be described as the illocution to catharsis and emotional revelation.

Next is superiority or disparaging humor. Humor associated with disparagement and superiority also invokes laughter. Gruner (1997) defined the power of humor in interpersonal relationships through his work with the superiority theory of humor. This theory has stated that humor is employed to create a social divide. Under this theory, Gruner (1997) framed all types of humor as a game, with the very essence consisting of "competition, keeping 'score' and a winner and a loser" (p. 2). Thus every joke has carried with it a winner, or audiences that are in on the joke, and a loser, the subject that is being made fun of. Audiences have laughed at jokes because it has exalted self-esteem, and it has built empathy with the sender of the joke (Bui, Kalpidou, DeVito, \& Greene, 2016). Schadenfreude-style humor is used as an abrasive or lubricating force within or between social groups as either self-deprecating or disparaging. Lynch (2009) analyzed the role of humor in a year-long ethnography, examining chefs as an organizational unit. Humor in the organization became a communicative process, establishing "the group's boundaries, the identity of the group members, and the processes through which the group makes sense of and performs its labor" (p. 127). In one part of the ethnography, managers would use aggressive humor to keep power in the organization. Lynch described the use of humor to reinforce in-group social norms and rules as control-type of humor. This would be like teasing an employee for being lazy (Lynch, 2009). Under the guise of humor in-group members have maintained the hierarchy and stay in power. The pecking order is the manager would be the winner and the subordinates are the losers.

Finally, there is incongruity theory. Meyer (2000) stated "people laugh at what surprises them, is unexpected, or is odd in a nonthreatening way" (p. 313). Rancer and Graham (2012) 
argued that the incongruity theory of humor is the cognitive process of understanding disparate, humorous ideas. Juxtaposing and contrasting unrelated concepts catches the audience off guard. This surprise invokes humor. The KUB model explained how ideas stem from three categories: known, unknown, and believed (Philip, Bongelli, Canestrari, Riccioni, Zuczkowski, 2013). Juxtaposing a non-threatening, abnormal idea with a one of the KUB categories allowed for the audience to sense incongruity and laugh. Not only can an audience laugh at a joke that sounds odd in nature, but as performers tell jokes in the style of a narrative, they begin to understand the context behind the incongruity. The incongruent resolution theory of humor supports that humor as a three step model: humor detection, resolution of incongruity and humor appreciation. Du, Qin, Tu, Yin, Wang, Yu, and Qiu (2013) conducted a study asking college students to judge whether certain stimuli were funny or not funny. Using ERP brain monitoring, scans conclude a change in certain parts of the brain. Understanding the incongruous nature of a joke, equated to participants appreciating the stimuli by laughing.

These three theories are the basis in which most humor is analyzed in research. That said, researchers have tried to codify and target types of humor and laughter within everyday life. Ruch (1992) attempted to make a barometer that tested the level of humor and categorized its impact using the $3 \mathrm{WD}$ humor test. This test has used humor preferences found in jokes and cartoons. This produced three types of humor: nonsense humor, which is laughable due to its ridiculousness, sexual humor, which categorizes offensive jokes, and incongruityresolution humor, which is "characterized by punch lines in which the surprising incongruity can be completely resolved" (p. 4). However, these categories created a somewhat narrow lens, since the taxonomy behind these humor types stem from only one-liners and cartoons. Martin \& Lefcourt, (1983) also assessed humor by focusing on how humor is associated with stress. 
Questions in this assessment have tried to bridge humor types that are often reflective of one's problem.

Berger (1993) catalogued four expressions of humor: logic, language, action, and identity. Logic refers to humorous ideation. Audiences laugh at absurdity and nonsense. For example, a logic-style joke could be: "Why do elephants paint their toenails red? So they can hide in cherry trees" (Berger, 1993, p. 18). Language plays with verbal expressions of humor, like insults or hyperbole. Action is the physical or nonverbal humor techniques, including slapstick and vaudeville. Finally, Berger described identity styles of humor as critiquing the self. This may include parodying a celebrity or mimicking. One form of identity humor is transformation which is the development, learning, exposure, and unmasking of the comic which reveals their character. This expression has dealt with how a comic has changed over time due to an incident or shift in identity. Burlesque and caricature performers use heightened forms of their identity to exaggerate a piece of themselves to an audience in a humorous way. Ultimately they reveal who they are through these performances. Comedians have equipped themselves with these techniques to show through humor how one transforms themselves, discloses concealed experiences, or reveals a more vulnerable version of their personality. Krefting (2014) stated comics playing with these techniques, depending on how tendentious the humor is, can range from eschewing oppressive structures to self-discovery. For example in 2006 the host of the Late Late Show, Craig Ferguson, humbly walked out on stage and greeted his audience. Rather than going into a humorous monologue, he began the show saying that his father had recently died. He explained to his audience that in the Celtic tradition it is customary to speak about their relatives who pass away by recounting stories about them. He joked to the audience, arguing that not all the stories are that flattering about the person, but all are humorous. Through his 
humorous and heartfelt monologue Ferguson transformed from a goofy talk show host to a more genuine person.

Some scholars look at humor and laughter through a lens of functionality (Martineau, 1972). He argued that humor is a lubricant or abrasive, enabling individuals to become more productive, likable, and trustworthy like a well-oiled machine. Martineau outlined some of the social functions of humor. He proposed a sociological model showing how humor within and between groups can solidify a group, cause conflicts within and social disintegration of a group, or cause conflict by redefining relationships between groups. Meyer (2000) advanced Martineau's model into a continuum, believing that humor unifies people through converging identities or divides people and creates a differentiation in status. Fine and Holyfield's (1996) study on joking culture stated that joking is connected to trust, and is embedded in the social relations in the group. From a small group perspective, humor is the force that holds people together. In this type of culture, the individuals ground their humor on shared emotion, and it is displayed through their jokes. This study focused on how humor is used to resolve a task or conflict. In the current social situation, humor remains a fluid-like, discursive idea. That said, humor is continuously analyzed through a narrow lens of its effects on others.

All of this is critical information, but studying humor and laughter through low-inference occurrences and pure function has only offered a narrow scope. Rarely has the research used these insights to reveal much about the humorist themselves. In other words, humor has historically been seen as a purely interpersonal concept. Berlyne (1969) argued that while some studies report the frequency of humor and humorous narratives, and their effects on interpersonal situations, there is scant research that has focused on the analysis on the form of communication and its intrapersonal value. This has created two issues. First it has completely disregarded other 
perspectives of humor and reasons why someone would laugh. Moreover, if the intrapersonal the value humor has for the sender of a joke - has been overlooked, our understanding of humor's true impact on people is limited. While in and of itself, humor and laughter are hard to reify, at the intersection of these concepts is something more tangible - the stand up comic.

\section{Comic's identity: A vulnerable expression}

Comedy, in particular stand up comedy, is performed for a multitude of reasons. These included critiquing institutions, playfully teasing others, introducing incongruous ideas on our society, and manipulating emotions - all with the goal to elicit laughter from an audience. From early on, stand-up comedy has been a staple in American identity. Due to humor's interpersonal nature "identity is visibly projected in concrete social encounters or communicative situations, when it is performed by speakers and recognized by the other participants." (Mada, 2015, p.108). Vinton (1989) showed how humor has reified solidarity in identity in a study regarding the socialization of employees. After spending seven weeks as a participant observer in a small organization, Vinton concluded that humor creates bonds between people. They begin to identify with one another. By introducing humor, group members may gain a stronger understanding of their peers' identities and perspectives. Humor in groups has allowed in-group members to empathize with multiple identities within the group, thus achieving a shared group cohesion. Humor then, defined shared group identities and generated positive relations (Couch, 1992). Couch furthered Martineau's idea and argued that humor should be studied as an inherently social phenomenon, with the unit of observation being not the individual but rather the symbolic transaction between people.

By in large, the body of literature discussing humor describes humor from either the perspective of the humorous message and/or from the person receiving the humorous message. 
This is parallel to describing comedy and a humorous narrative. The schema surrounding the comic and their role in humor dates back to Freud (1976/1905). The comic, known as the sender or the person employing the joke, is vital to the humor and joke-making process. In fact, Freud (1976/1905) structured humor as three vital persons: the person employing the joke, the person the joke is targeting, and the third person that gets pleasure from that stimulus. However, Oring (1992) stated within the context of interpreting humor "an encounter with the individual joke teller has been considered superfluous" (p. 94). Again, the schema is inherently interpersonal and benefitting the audience. The combination of broad definitions and focusing only on the interpersonal functions ultimately makes the study of humor shortsighted and does not unearth the true value that humor has. Therefore, in order to gain a more accurate analysis of the value humor brings, there must be more of an effort to understand the value humorous narratives have on the sender. Boskin (1997) described this perfectly when he wrote about interviewing his professors and asking them why they use humor in class. Their findings classify humor ranging from "unintentional to the deliberate" (p. 13). However, some "reached for a more intimate experience" (p. 13). This intimate experience is akin to understanding the intrapersonal experience of humor. Much like how a comic creates comedy in order to benefit themselves, Boskin (1997) recalled "out of these instances came a conscious attempt to develop a comic spirit" (p. 13). In order to push the conversation forward about comedy and its place in our personal lives, it is imperative to analyze comedy from the perspective of the sender (i.e., comic).

Until about the 1950s the comic was seen as a means to an end. In other words, the comics themselves were not involved in the process of creating jokes. Writers from vaudeville to radio to nightclubs lifted jokes from other comics (Nesteroff, 2015). Anybody could be a comic is if they had the right writer and a little luck. Vaudeville overtook the 1920s. At that time, 
comics of that era, like George Jessel and the Marx Brothers, lived arduous lives. They were vagrants moving from one theater to the next (Nesteroff, 2015). Back then, comedy was a family business. Comics Buster Keaton, The Three Stooges, and Milton Berle were simply a mouthpiece and jokes were surface-level and physical. Humor throughout history was also disconnected from the performer. Jokes were told in the third person and the structure of jokes were similar to each other. Everyone had the same jokes. The comedians in early stand up comedy would use more word play, puns, and aggressive humor. In fact, Nesteroff illustrated that comics during the rise of the nightclubs were, in some respects owned by the mob. If the mob did not approve of a joke, the comic did not say it. Insult comedy clubs were created that procured comics that used disparaging humor, notifying the mafia or any other patron a warning that they were paying to get made fun of throughout the night.

Humor that is aggressive and self-enhancing aligns with fostering a common group identity. If an audience member decides to heckle a stand up comedian, it may be in the comedian's best interest to retaliate by employing a playfully aggressive type of humor. By teasing the audience member, the comedian builds a social affiliation with the rest of the audience, and thus maintains the group identity. Tajfel and Turner's (1986) Social Identity Theory (SIT) supports this claim. SIT surmised that social acceptance from a group allowed individuals to categorize themselves in a positive light within a larger context (Tajfel \& Turner, 1986). Therefore, acceptance gained through humor increased the group's positive connections with one another, displayed empathy for others, and achieved a sense of a shared group identity. Abrams and Bippus (2011) investigated how men and women perceive disparaging (sexist) humor towards one another. The results supported SIT. This study revealed that the genders were partial to their group's collective identity, finding jokes about the opposite gender funnier, and 
empathizing with members who were offended with jokes about their own gender (Abrams \& Bippus, 2011). What this study showed us when their goal is to achieve unity within a group, humor enabled individuals to selectively elicit empathy within their group, allowing them to be more personal with them.

Oring (1992) illustrated the intersection of humor, laughter and the comic, describing it as discovery between the performer and the audience through laughter. In order for that to happen the comic - or sender - must be willing to give their point of view. Certainly comics can espouse the logic or verbal play of comedy and have prolific careers. However, after the 1950s comics transitioned to more personal humor (Nesteroff, 2015). This style of humor gave comedians a way to brand their own material, thus securing it from other joke writers, as well as expand on what they wanted to talk about. No longer was stand up comedy just a space for oneliners. Double (2014) expressed that soon a comic needs to dive deeper since "stand up is a form of self- expression" (p.114). What is known as sick comics started to surface.

These comics were darker in nature, and they were not afraid to push humor limits. Rather than traditional standups, sick comic Mort Sahl and others became cultural anthropologists critiquing the human condition from all angles (Koziski, 1984). A Time Magazine (1959) article titled "Sickniks" paralleled the new, unorthodox style of humor to that of a sickness, criticizing the sick comics use of humor, despite their popularity. The article reported "it's like the last days of Rome - all this horror and mayhem in humor" (Time, 1959, p. 44). Back in the 1950s, Sahl's focus was mostly about the cynicism in politics. Nachman (2003) quoted Sahl, saying his style allowed him to act "like a human being rather than a nightclub comedian" (p. 94) The sick comics from the 1950s through the 1970s became a catalyst that launched the comedian into a more dynamic entity. Also known as a comic's comic, sick comics 
like George Carlin and Lenny Bruce pushed censorship in media. Bill Hicks polemically spoke about military and government misconduct. Elaine May, Mike Nichols, and others were foundational in carving out the new identity of the comic performer. By the 1980s, 1990s and 2000s, the comedian could explore more than their predecessors, including their shortcomings.

\section{Coping with hardships via humor: Resilience and therapy}

Hardships are a part of life. However, Kabat-Zinn (1990) argued to embrace such destitution. Berger (1993) stated that laughter is naturally valuable to us humans. It is in our biology. Additionally, Berger wrote “'humor' fosters creativity, helps prevent obsessive behavior, encourages playfulness and openness, purges us of violent emotions or feelings of excessive guilt, reveals that authority is often invalid, liberates us, helps promote social cohesion, and provides great pleasure" (p. 162). DiCioccio (2012) argued that humor is used as a social tool that "fosters positive feelings and encourages a sense of kinship yet it can also act as a demonstration of aggression" (p. 94). When people feel down and could really use a laugh, there is more communicative power behind that expression. Humor not only can affect a person's feelings, but also, DiCioccio argued that "humor, when used appropriately, can create or shift the emotional charge of an interaction. Whether through subtle means or overt contrast, humor has direct impact on the emotional state of relational partners" (p. 34). DiCioccio stated humor "as a communicative act that can serve single or multiple cognitive emotional, and relational functions" (p. 53). These functions are catharsis and resilience. Not only does humor incorporate great healing power, both physically and when used as therapy for stress or coping, but it has also been found to build up resilience and self-image among younger people going through a watershed problem in their lives (Dicioccio, 2015). This is evidenced by the study of narrative medicine within the healthcare industry. Since $2007,45 \%$ of healthcare companies carry with 
them an arts program, with over $20 \%$ of those programs being performance based (State of the Field Committee, 2009). Additionally, the State of the Field Committee (2009) reported that performers and storytellers make up roughly $15 \%$ of types of "professionals providing services in hospitals" (p. 5). Through these programs, narrative therapy enabled patients to "helps patients revise, or "re-author" personal stories of suffering that prevent forward movement in therapeutic treatment" (Rian \& Hammer, 2013, p. 675). Patients have used narrative therapy to reframe their perceptions and realities. This method has been used to help patients confront or evade their crises and move towards healing.

Additionally, humor has allowed audiences to feel resilient about their lives. If the audience can laugh, Dicioccio (2015) stated, "resilience is evidenced by sustainability, recovery, or a combination of both" (p. 7). Comedian Tig Notaro (2012) took the stage and started her comedy set with "hey how are you, I have cancer." She proceeded to talk about the many obstacles that she had faced before getting cancer, including her diagnoses with C-Diff, a bad break up, and her mom dying. Notaro's (2015) honest style of humor allowed her to connect with the crowd which was roaring with laughter. Her unorthodox comedy routine gave her the resilience and hope to move forward with her life and her career. Snyder (2002) defined humor in terms of resilience by writing the "positive motivational state that is derived from a sense of accomplishment in recognizing one's desired goals and being able to successfully meet those goals. As such, positive emotion should flow from perceptions of successful goal pursuit" (p. 252). This behavior has been seen in Booth-Butterfield, Booth-Butterfield, and Wanzer's (2007) study of humor and resilience. They found high humor-oriented students reported greater coping efficacy. Additionally, Cann and Etzel's (2008) study examined relationship among humor and stress and concluded participants' greater use of humor was associated with higher levels of 
happiness and optimism and lower perceptions of stress. This type of humor arms a person with a sense of control and stability during hardship. Both these studies illustrated how invoking and appreciating humor enabled people to have emotional control and can give them the strength to move forward with their lives. Ultimately these discourses surrounding humor argued that humor is an experience that has value for all people involved. As humor continues to be an experiential force, it is imperative to see how this variable is also just as valuable for the sender.

Therapists often will use humor as part of their method to help their patients. Grotjahn (1970) stated "laughter in therapy is welcome like any sign of spontaneity, strength, mastery, and freedom" (p. 66). Humor can also operate in a deconstructive mode, often reversing the normative reality into something new (Fry, 1963). Hoyt and Andreas (2015) expanded on this notion, highlighting how humor can cause someone to be forgiving. In their article, Hoyt specifically explained a patient he worked with was angry with his girlfriend and how she handled money. The patient is Jewish, but his girlfriend is not. Hoyt is Jewish himself, so he told a disparaging, Jewish joke that flippantly poked fun at the the Jewish people's money-oriented stereotype. An old Jewish couple has a failing business. They need money or else they go under for good. They find a church willing to pay money for converts. After some arguing the man gets converted. When he comes out, he never gets the money but instead accuses his wife for her so called greediness. The punchline of the joke is "what's with Jews and money?" (Hoyt \& Andreas, 2015, p.16). The patient laughed and told Hoyt that he would tell his girlfriend that joke. Shifting the issue by using a humorous lens presented an incongruous frame of reference that emphasized how funny the fight is in the grand scheme of things, which led patients to forgive others and themselves. The patient's response favorably showed that he was willing to mend his relationship with his girlfriend, and maybe reassess his own behavior. The example in 
Hoyt and Andreas (2015) article further illustrated how humor can reframe the situation for the patient. Humor in therapy allows for patients to comprehend a new perspective about their dispositions. Panchelli (2013) addressed what effects humor has on reframing in psychotherapy. Panchelli described two techniques social workers use to help their patients persevere through a watershed. Joining is the process understanding the patient's experience through empathy. Reframing is the ability to shift or transition one's mindset. Both techniques are necessary to help patients cope with a hardship, but trying to utilize both cannot work since reframing forces the therapist to no longer join with the patient. Panchelli's article articulated how humor can positively bridge the joining and reframing processes. Humor, in this context, acts as a shared worldview that brings both the therapist and patient on common ground. By using humor to reframe the patient's hardship, the patient can accept reframing techniques while keeping their trust with the therapist. This study may directly relate to how comics can use the aforementioned humor techniques to confront their own hardships in life.

Conceptual Shows. Humorists started to present in more innovative ways. The traditional style of stand up comedy is still very much around. Comedy Central half hours will still highlight upcoming comics. Comedians Kevin Hart and Amy Schumer, and many others like them, are crafting their new hour comedy specials. However, the institution of the comic standing behind a microphone has drastically changed since the 1950s, and well past the late 2000s. Double (2014) noted that conventional stand up is consistently challenged, and new manifestations of comedy are forming. The comedian is beginning to leverage their humor as a sort of therapy. For example, conceptual shows are becoming somewhat popular. Conceptual shows veer away from a comedian telling a funny story or reciting a laundry list of tangential jokes. In his review for the New York Times, David Richards (1992) New York Times review saw 
conceptual solo shows as the genre to discover about one's self in an entertaining way. In this type of show Double (2014) noted "the comic takes the audience on a journey, which can allow tonal shifts, quieter passages, raw emotion, exploration of ideas and a sense of building to a satisfying understanding (p. 88). Bo Burnham, one of comedy's latest sick comics, recently completed his newest solo show "Make Happy” (Burnham, 2016). Through stand up and musical comedy, Burnham presents a conceptual show that mixes his absurdist, satirical humor as a gateway to inform the audience about his mental illness. Conceptual shows, like Burnham's, display a more sustained story line or concept that he addresses to the audience. It is in situations like these that the sender becomes just as much of a participant as the audience.

Fueling a narrative with jokes, such as a concept show, enables the comic's tendentious behavior, not just a transactional model of communication, but more like a prism. That is, with multiple beams that represent the multitude of perspectives humor affects. Thus, humor is seen as a tool that can bring order to our emotional states. Krefting (2014) noted that "stand up comedy is a mode of performance for which there are many variables and styles" (p. 3). This brings us to a new intersection of humor. The tectonic plates of comedy shift from a presentational performance of one-liners and bits to a unique form of storytelling and selftherapy where the comic plays both the patient and the therapist, inviting the audience to join in their experience while they discover how they reframe it. This style of performance aligns with Orkibi's (2010) performance theory "being-via-drama" (p. 198). In this style of performance, performers "undertake the role of both participant and observer by means of the dramatic medium" (Orkibi, 2010, p. 198). It is in this context that the sender of the humorous message takes center stage and is the most vulnerable. 


\section{Sensemaking: Uncovering an authentic identity}

At a Moth reading in 2011, former host of the children's show Blue's Clues, Steve Burns, stood on stage (Burns, 2011). Burns dove into a story about gallivanting with a little blue puppy, and other memories of his time during the show, both on and off camera. He spoke about the incongruity he experienced between his identity as Steve from "Blue's Clues," and his identity as Steve Burns. His style of storytelling was interactive and funny, allowing both him and the audience to make sense of his identity-crisis through laughter. Sensemaking is defined as “meaning making” about one's identity (Schwandt, 2005, p. 182). Narratives are more than just stories, they have also revealed a truth about the storyteller and the audience. There has been scant research on identity humor and sensemaking (Tracy, Meyers, \& Scott, 2006). However, Grotjahn (1970) stated "jokes can be used as an excellent method to give an interpretation. The therapist has used it consciously; the patient has done it unconsciously" (p. 62). Fischer (1985) elucidated that a narrative means more than the "individuated parts that compose it" (p.1). In his essay, Fischer (1985) attempted to extend the narrative paradigm to illustrate its value in communication. Fischer described the purpose of the narrative paradigm and narratives is to understand how people use stories to transcend simple description, evaluate their actions, and discover new meanings in life. In other words, narratives go beyond the social science reality and discover a higher truth. For the comic, the relationship between jokes and the comic is that jokes allow comics to access a humorous experience (Nueve, 1988). Furthermore, humor is this distinct process that allows the comic to make sense of the world around them (Freud, 1905/1976; Pirandello, 1974). Freud explained, "as regards to jokes, we know that the sources of the pleasure that is to be fostered like in the subject himself and not in outside people" (p. 239). Much like a narrative or story, a joke has multiple parts as well. Suls (1983) described how jokes 
are compiled of employing and receiving a joke. Think jokes as set up and punch line. Suls extended these ideas to formulate a narrative which was used to predict our behavior. All these parts are necessary for the joke to survive, but the meaning behind the joke has not ascribed to only one of these parts. That is, narratives allow us to understand a lesson learned by the comic. Not only can an audience laugh at a joke that sounds odd in nature, but as jokes are being told in the style of a narrative, audiences begin to understand the reason behind the incongruity. Especially if that incongruity deals with parts of themselves such as their identity.

For example, Chirico's (2016) analyzed comedian David Sedaris's monologue. Sedaris is a comedy author, performer, and monologist. One of his monologues was called The Santaland Diaries. In this monologue, Sedaris described a terrible event when he worked as an elf at a Santaland at Macy's. On the surface he used self-deprecation to confess his inferior identity as an elf, but also as another identity. He also revealed to us a side of him grappling with his career choices. To Chirico (2016) humor in this monologue demarcates the insider's voice-the theatrical aside - and indicates a self that the Santaland customers do not normally see but that Sedaris revealed to his audience. By laughing at himself - at the situation he has put himself in he was able to juxtapose his two identities side-by-side and revealed a more authentic self to the audience (i.e., the elf that is artificial but public and his authentic yet private self). Comedy in this narrative has mapped Sedaris's story from goofy Santaland elf, to jaded employee, to overall balanced person. Like the concept of synergy, the sum of his splintered identities (the caricature of the elf, the jaded character of a bad employee, and the vulnerable self) are pieced together to show a more authentic person. Freud (1976/1905) described how this incongruity allows us to "attach sense to a remark and know that logically is cannot have any. We discover truth in it, which nevertheless, according to the laws of experience or our general habits of thought, we 
cannot find it" (p. 42). Freud wrote "the discussion of bewilderment and enlightenment brings us closer to a particular discovery" (p. 43). It is our responsibility as the audience to decrypt the humorous message to understand its higher meaning. Thus, when the humor is resolved in a story the audience "gets it" and laughs. The watershed experiences comics and people deal with can be painful. Performance is one way for the performers to undergo a shedding of skin, reveling in their awkward circumstances to convey a more serious, painful part of themselves. Their performances become performed journeys. In their ultimate quest to achieve a stable emotional mental state these types of comics are akin to patients in Frank's (1995) concept of the wounded storyteller. He stated "narrative tells self-consciously of being transformed; undergoing transformation is a significant dimension of the storyteller's responsibility (Frank, 1995, p. 118). This idea goes further as that comedy becomes the channel, in which comedians can reify their new mental well being. Chirico (2016) stated "stand up comedy as an art form in which comedians establish observational distance from their experiencing self in order to transform stories of pain or humiliation into the stuff of comedy" (p. 23).

Chirico (2016) delivered an adequate response to understanding how a comic, or anyone, can truly perform authentically:

Performing authenticity goes beyond a simple acknowledgment of biographical truth. Behaving authentically is a practice of being true to one's self despite the pressures of society. Thus, in order to perform the authentic self, the monologist has to enact both the public mask everyone wears and provide a sense of a deeper self within. (p. 25). 


\section{Reifying the literature: Documentary proposal}

This is where the documentary fits in the larger conversation, asking what intersections does humor actually communicate? Ian Brodie (2008) argued that a humor is a form of intimacy. With the above information, a new theory of humor may emerge. Humor is the process of safely communicating vulnerability. This documentary will explore the many facets of how humor can establish authenticity, intimacy, and identity as the participants undergo a retelling of a watershed moment in their lives. Throughout the documentary, the following research questions will be in play:

- RQ1 What is the effect of creating a humorous narrative to make sense of a serious event?

- RQ2 What effects do humorous narratives have on achieving emotional closure or coping?

- RQ3 How will employing humorous narratives help construct a user's identity?

With this in mind, this documentary discovers the ways in which identity is reconstructed, as well as how humor could help people find closure and make sense of the hardship in their lives. 


\section{REFERENCES}

Abrams, J. R., \& Bippus, A. M. (2011). An intergroup investigation of disparaging humor. Journal of Language and Social Psychology, 30, 193-201. doi:

$10.1177 / 0261927 X 10397162$

Bakhtin, M. (1984). Rabelais and his world. Trans. Hélène Iswolsky, Bloomington, IN: Indiana University press

Bateson, G. (1953). The position of humor in human communication. In Cybernetics, ninth conference (Vol. 147.)

Becker, A. B., \& Haller, B. A. (2014). When political comedy turns personal: Humor types, audience evaluations, and attitudes. The Howard Journal of Communications. 25, 34-55. doi: $10.1080 / 10646175.2013 .835607$

Berger, A. A. (1993). An anatomy of humor. New Brunswick USA and London U. K.: Transaction Publishers

Berlyne, D. E. (1969). Laughter, humor, and play. In G. Lindzey \& E. Aronson (Eds.). Handbook of social psychology (2nd ed., Vol. 3) Reading, MA: Addison-Wesley

Booth-Butterfield, M., Booth-Butterfield, S., \& Wanzer, M (2007). Funny Students Cope Better: Patterns of Humor Enactment and Coping Effectiveness. Communication Quarterly, 55(3). 299-315. doi: ttp://dx.doi.org/10.1080/01463370701490232

Boskin, J. (1997). The humor prism. Detroit, MI: Wayne State University Press.

Brodie, I (2008). “Stand-Up Comedy as a Genre of Intimacy,” Ethnologies 30(2) 153-180. doi: https://doi.org/10.7202/019950ar

Bui, P., Kalpidou, M., DeVito, L., and Greene, T. (2016). The effects of empathy on disparagement humor. Psi Chi Journal of Psychological Research. 21(2). 119-126 
Burns, S. (2011) Fameishness. The Moth.

Cann, A., \& Etzel, K. C. (2008) Remembering and anticipating stressors: positive personality mediates the relationship with a sense of humor. Humor, 21, 158-178. doi: https://doi.org/10.1515/humor.2008.008

Chirico, M. (2016). Performed authenticity: Narrating the self in the comic monologues of david Sedaris, john leguizamo, and spaulding gray. Studies in American Humor. 4(1), 22-46. doi: https://doi.org/10.5325/studamerhumor.2.1.0022

Richards, D. (1992). The minefield in monologues. New York Times. 1-2 Retrieved from http://www.nytimes.com/1992/07/12/theater/sunday-view-the-minefields-inmonologues.html?pagewanted=1

DiCioccio, R. L. (2012). Humor as aggressive communication. In R.L. DiCioccio (Ed.). Humor communication: Theory impact, and outcomes (pp. 93-108). Dubuque, IA: Kendell Hunt

DiCioccio, R. L. (2015). We could sure use a laugh: Building hope and resilience through humorous communication. In G. A. Beck \& T. J. Socha. (Ed.). Communication hope and resilience across the lifespan (pp.34-52). New York, NY: Peter Lang Publishing.

Double, O. (2014). Getting the joke: The inner workings of stand-up comedy. London: Bloomsbury Methuen Drama

Du, X., Qin, Y., Tu, S., Yin, H., Wang, T., Yu, C., \& Qiu, J. (2013). Differentiation of stages in joke comprehension: Evidence from an ERP study. International Journal of Psychology, 48(2), 149-157. doi: http://dx.doi.org/10.1080/00207594.2012.665162

Frank, A.W. (1997) The Wounded Storyteller: Body, Illness, and Ethics. New York: University of Chicago 
Freud, S. (1976). Jokes and Their Relation to the Unconscious (J. Strachey, Trans.). New York: W.W. Norton \& Co, 1960 (Original work published 1905).

Fry, W. F. (1963). Sweet Madness: A Study of Humor. Palo Alto, CA: Pacific Books Publishers. Grotjahn, M. (1970). Laughter in Psychotherapy. In Mendel, W. M. (Eds.), A celebration of laughter (pp. 61-66). Los Angeles, CA: Mara Books Incorporated

Hoyt, M. F. (2009). Brief psychotherapies: Principles and practices. Phoenix, AZ: Zeig, Tucker, \& Theisen.

Hoyt, M. F. \& Andreas, S. (2015). Humor in brief therapy: A dialogue part 1. Journal of Systemic Therapies. 34(3), 14-25. http://dx.doi.org/10.1515/humor.2008.008

Kabat-Zinn, J. (1990). Full catastrophe living: Using the wisdom of your body and mind to face stress, pain, and illness. New York, NY: Delta

Koziski, S. (1984). The standup comedian as anthropologist. Journal of Popular Culture, 18(2), 57-76. doi:10.1111/j.0022-3840.1984.1802_57.x

Krefting, R. (2014). All joking aside: American humor and its discontents. Baltimore, US: Johns Hopkins University Press. Retrieved from http://www.ebrary.com

LaFave, L., Haddad, J., \& Maesen W A (1976). Superiority, enhanced self-esteem and perceived incongruity humor theory. In A. J. Chapman \& H. C. Foot (Eds.). Humor and laughter: theory and research (pp. 63-93). New York: Pergamon Press

Lovorn, M.G. (2008) Humor in the home and in the classroom: The benefits of laughing while we learn. Journal of Education and Human Development, 2(1), p. 1-12

Lynch, O. H. (2009). Kitchen antics: The importance of humor and maintaining professionalism at work. Journal of Applied Communication Research. 37(4). 444-464. 
Mada, S. (2015). Building Identity in humorous media interactions. Language and Dialogue. 5(1), P.107-127 doi 10.1075/1d.5.1.06mad

Martin, R. A, \& Herbert M. Lefcourt, H. M. (1983). Sense of humor as a moderator of the relation between stressors and moods. Journal of personality and social psychology. 45(6), p. 1313-1324

Martin, R. A. (2007). The Psychology of Humor: an integrative approach. Burlington, MA: Elsevier Academic Press

Martineau, W. H. (1972). A model of the social functions of humor. In J. H. Goldstein \& P. E. McGhee (Eds.), The psychology of humor: Theoretical perspectives and empirical issues (pp. 101-125). New York, NY: Academic Press.

Meyer, J. C. (2000). Humor as a double-edged sword: Four functions of humor in communication. Communication Theory, 10, 310-331. doi:10.1111/j.14682885.2000.tb.00194.x

Nabi, R. L., Moyer-Guse, E., \& Byrne, S. (2007). All joking aside: A serious investiga- tion into the persuasive effect of funny social issue messages. Communication Monographs, 74, $29-54$

Nachman, G. (2003). Seriously funny : the rebel comedians of the 1950s and 1960s. New York : Pantheon Books

Nesteroff, K. (2015). The comedians: Drunks, thieves, scoundrels and the history of American comedy. New York, NY: Grove Press

Notaro, T. (2012). Hello, I have cancer [Audio]. Tig Notaro Live Retrieved from https://www.youtube.com/playlist?list=PLT-eqUbLJ5CH1E_xVfmDfAuZP0YHxoV26 
Nueve, M. (1988). Freud's theory of humor, wit and jokes. In J. R. Durant (Eds.) Laughing matters: A serious look at humor (pp. 35-43). New York, NY: Longman Scientific \& Technical.

Oring, E. (1992). Jokes and their relations. Lexington, KY: The University Press of Kentucky

Orkibi, H. (2010). The experience of acting: A synthesis of concepts and a clinical vignette. Journal of Applied arts and Health. 1(2), p.193-203.doi: 10.1386/jaah.1.2.193_1

Panchelli, C. (2013). Humor, joining, and reframing in psychotherapy: Resolving the autodouble-bind. The American Journal of Family Therapy. 41, 437-451. doi: $10.1080 / 01926187.2012 .755393$

Philip, G., Bongelli, R., Canestrari, C., Riccioni, I., \& Zuczkowski, A. (2013). “Negotiating Narrative: Dialogic dynamics of known, unknown and believed in harry potter and the deathly hallows. Language \& Dialogue 3(1), 6 - 32. doi: 10.1075/ld.3.1.02phi

Pirandello, L. (1974). On Humor (A. Illiano \& D.P. Testa, Trans.). Chapel Hill, NC: The University of North Carolina Press.

Rancer, A.S. \& Graham, E.E. (2012). Theories of humor. In R.L. DiCioccio (Ed.). Humor communication: Theory, impact, and outcomes. (pp. 3-10). Dubuque, IA: Kendall Hunt.

Rian, J. \& Hammer, R. (2013). The practical application of narrative medicine and mayo clinic: Imagining the scaffold of a worthy house. Culture, Medicine, and Psychology, 37, 670680. doi: $10.1007 / \mathrm{s} 11013-013-9340-0$

Ruch, W. (1992). Assessment of appreciation of humor: Studies with the 3 WD humor test. In C. D. Spielberger \& J. N. Butcher (Eds.), Advances in Personality Assessment (Vol 9). Hillsdale, NJ: Lawrence Erlbaum Associates, 27-75 
Scanlon, C., \& Burnham, B., \& Storer, C. (Co-directors). (2016). Make happy [Motion picture]. USA: Madison Square Garden

Schwandt, D. R. (2005). When managers become philosophers: Integrating learning with sensemaking. Academy of Management Learning and Education, 4(2), 176-192.

Self, J.W. (2011). A (not so) laughable political argument: A close textual analysis of the daily show with john stewart. In T. Goodnow (Ed.), The daily show and rhetoric arguments, issues, and strategies (pp. 59-76). Plymouth, UK: Lexington Books

Sickniks. Time, 135, 28-31. 44

Snyder, C. R. (2002). Hope theory: Rainbows in the mind. Psychological Inquiry, 13, 249-275. doi: http://dx.doi.org/10.1207/s15327965pli1304_01

State of the Field Committee (2009). State of the Field Report: Arts in Healthcare 2009.

Washington, DC: Society for the Arts in Healthcare. Accessed

http://legacy.arts.ufl.edu/cam/documents/stateofthefield.pdf

Suls, J. M. (1983). Cognitive Processes in humor appreciation. In P. E. McGhee and J. H. Goldstein (Eds.), Handbook of humor research (pp 39-57). New York, NY: Springer

Tajfel, H., \& Turner, J. C. (1986). The social identity theory of intergroup behavior. In S. Worchel \& W. G. Austin (Eds.) Psychology of intergroup relations (pp. 7-24). Chicago: Nelson-Hall.

Tracy, S. J., Myers, K. K., \& Scott, C. W. (2006). Cracking jokes and crafting selves: Sensemaking and identity management among human service workers. Communication Monologues, 73(3), p. 283-308. doi: 10.1080/03637750600889500 
Vallade, J. I., Booth-Butterfield, M., \& Vela, L. E. (2013). Taking back power: Using superiority theory to predict humor use following a relational transgression. Western Journal of Communication, 77(2), 231-248. doi: 0.1080/10570314.2012.669018

Zillman, D., \& Cantor, J. R. (1976). A dispositional theory of humor and mirth. In A. J. Chapman \& H. C. Foot (Eds.). Humor and laughter: Theory and research (pp. 93-115). New York: Pergamon Press 